\title{
The effects of the timing and method of logging on forest structure in Peninsular Malaysia
}

\author{
Ho Wei Seng ${ }^{\mathrm{a}, *}$, Wickneswari Ratnam ${ }^{\mathrm{b}}$, Shukor Mohamad Noor ${ }^{\mathrm{b}}$, \\ Mahani Mansor Clyde \\ ${ }^{a}$ Faculty of Resource Science and Technology, Universiti Malaysia Sarawak, \\ 94300 Kota Samarahan, Sarawak, Malaysia \\ ${ }^{\mathrm{b}}$ School of Environmental and Natural Resource Sciences, Faculty of Science and Technology, \\ Universiti Kebangsaan Malaysia, 43600 Bangi, Selangor Darul Ehsan, Malaysia
}

Received 14 October 2003; received in revised form 22 June 2004; accepted 21 July 2004

\begin{abstract}
We investigated the effects of immediate, short-term (2.5 years after logging) and long-term (about 50 years after logging) logging on tree species from different diameter size classes in three forest reserves in Peninsular Malaysia. Demographic data on number of trees, species and diameter of all trees above $1 \mathrm{~cm}$ diameter at breast height (dbh) were measured from three ecological plots $(20 \mathrm{~m} \times 50 \mathrm{~m})$ established at different elevations in each study site. The total reduction in mean basal area for trees $\geq 1 \mathrm{~cm}$ dbh for both logged stands was significantly different $(P<0.05)$, i.e. $50.9 \%$ in Compartment 118 and 51.8\% in Compartment 48. All trees more than $60 \mathrm{~cm}$ dbh in Compartment 118 and $75 \mathrm{~cm}$ dbh in Compartment 48 were felled in a single selective cutting under selective management system (SMS). The removal of these genetically superior adult trees will affect the genetic quality of the remaining and subsequent regenerating gene pools. The mean basal area and tree density for seedling and sapling class $(<5 \mathrm{~cm} \mathrm{dbh})$ were reduced to one-half of the original stand in Compartment 118 after logging, meanwhile an increment of $24.3 \%$ was observed in Compartment 48, 2.5 years after logging. This implies that the logging operation favoured the growth of seedlings and saplings. The net loss in trees was offset by incremental growth in surviving trees. Good regeneration was observed in the regenerated stand of Compartment 69 (RS-C69) with $28.5 \%$ and $20.5 \%$ more, respectively, in basal area and tree density for seedling and sapling class compared to Compartment 118 before logging. There were no distinct changes in species composition before and after logging in this study. The high negative correlation of basal area with relative disturbance index was observed in Compartments 118 and 48 based on botanical name or native name, indicating that the degree of disturbance was affected by the type and magnitude of disturbances in each of the localities in the compartment. This further implies that a logging operation in the compartment is not a homogeneous activity. The current harvesting system (i.e. SMS) in Peninsular Malaysia should consider the abundance of young regenerants and the genetic quality of the residuals left behind in the postharvest stands. The current mechanized logging techniques also need to be improved by adopting the reduced impact logging
\end{abstract}

\footnotetext{
* Corresponding author. Tel.: +60 82671 000x284; fax: +60 82672275.

E-mail address: wsho@frst.unimias.my (H.W. Seng).
} 
(RIL) techniques, so as to promote regeneration of desired commercial timber species and as a consequence, sustainability of the forests.

(C) 2004 Elsevier B.V. All rights reserved.

Keywords: Forest structure; Selective logging; Shorea curtisii; Disturbance; Forest management; Tropical forestry

\section{Introduction}

Traditionally, the timber industry has been one of the main income generating resources used in developing a country's economy. In the early 1980s, 4.4 million ha of undisturbed closed tropical forest were logged and another 1.1 million ha were degraded annually (Johnson and Cabarle, 1993). Since forests are not only a valuable source of timber but also provide a wide range of non-timber forest products (NTFPs) as well as major environmental services, the principle of sustainable forest management is to harvest the natural forest resource (including NTFPs) without compromising its social and ecological value (Sist et al., 1998). Conventional or mechanized logging, if uncontrolled can have high damaging effect on forest structure, composition and regenerating capacity. Hence, harvesting techniques often need to be controlled to decrease residual damage to acceptable levels for achieving sustainable forest management (Pinard et al., 1995; Pinard and Putz, 1996). Damage control during logging is an important factor in retaining the potential for natural regeneration of the desired commercial species (Webb, 1997). The extent of damage is largely determined by the felling intensity, that is the number or volume of trees felled per hectare (Hendrison, 1990) but strongly influenced by the nature of the logging practices (Webb, 1997).

The volume of timber extracted varies from region to region according to the stocking of commercially valuable stems. The number or volume of trees harvested from Asian dipterocarp forest tend to be high, with the average ranging from 8 to 10 trees ha ${ }^{-1}$ or 90 to $150 \mathrm{~m}^{2} \mathrm{ha}^{-1}$ not being unusual (Cannon et al., 1994; Pinard and Putz, 1996; Sist et al., 1998). Levels of extraction and damage in Latin America tend to be less but vary with different countries and forest types (Uhl and Vieira, 1989; Johns et al., 1996; Mason, 1996; Webb, 1997). Logging intensity in Africa is generally the lowest of the three tropical regions due to high costs and low local demand and a limited number of species used for the export market (White, 1994; Chapman and Chapman, 1997). It is therefore not surprising that logging commonly damages more than $50 \%$ of the original tree population (Pinard and Putz, 1996; Bertault and Sist, 1997). An acceptable level of timber harvesting is difficult to define. It is easier to analyse destructive felling intensities than to determine the critical levels for safe timber harvesting operations. However, recent experiments demonstrated that reduced impact logging (RIL) can reduce damage to a stand by 30-50\% (Pinard and Putz, 1996; Bertault and Sist, 1997).

Selective logging has been widely argued the most important management intervention in a selective silviculture system. According to Webb (1997), selective logging is a harvesting system that produces disturbances similar to natural tree fall gaps. Under optimal conditions, selective logging does not significantly change forest structure (Matthews, 1989), but stimulate natural regeneration and growth with the formation of gaps (Hartshorn, 1989). The impacts of logging include the direct effects of the felling of harvested trees and associated damage to the residual stand where a large proportion of the remaining vegetation may be killed or damaged. Removal of a significant proportion of mature trees will reduce the potential seed sources for subsequent regeneration. Logging also leads to significant disturbance to the soil and water catchments caused by the felling of trees and the construction of logging roads and skid trails (Van Gardingen et al., 1998). These effects of logging will directly influence the ecological processes involved in the establishment of seedlings and subsequent regeneration of the stand, and can significantly alter species composition and stand structure (Cannon et al., 1994).

In Peninsular Malaysia, logging damage to the residuals using selective management system (SMS) is estimated to be about $30 \%$ for trees above $30 \mathrm{~cm} \mathrm{dbh}$ (Griffin and Caprata, 1977), but Burgess (1971) 
estimated that the basal area destroyed amounts to $55 \%$ for the extraction of only $10 \%$ of the basal area of timber. Canonizado (1978) estimated that logging damage is about $69 \%$ for trees $15-30 \mathrm{~cm}$ dbh and $64 \%$ for trees 30-50 cm dbh, based on a study in Jengka, Pahang. Wyatt-Smith (1954) observed that following logging, damage increased progressively and lasted for several years. This is because many trees that are only partially affected during logging may appear well initially, but could die several years later. Appanah and Weinland (1990) found that heavy damage from windthrow on a Shorea curtisii richridge top forest several years after logging. Therefore, this will raise logging damage beyond the tolerance level of $30 \%$ as estimated by Griffin and Caprata (1977).

The aims of this paper are: (1) to investigate the effects of immediate, short-term (2.5 years after logging) and long-term (about 50 years after logging) logging on tropical tree species from different diameter size classes; and (2) to estimate the relative levels of disturbances on tropical tree species. The results obtained from this study can be used to improve the current general guidelines on pre-felling, logging and post-felling practices in Peninsular Malaysia (i.e. SMS) in order to promote regeneration of desired commercial timber species and as a consequence, sustainability of the forests.

\section{Materials and methods}

\subsection{Study sites}

Three forest reserves with commercial logging activity were chosen for this study viz. Ulu Sedili Forest Reserve and Panti Forest Reserve in Johor, and Serting Tambahan Forest Reserve in Negeri Sembilan, Malaysia (Table 1).

The Ulu Sedili F.R. is situated about $40 \mathrm{~km}$ north of Johor Bahru. The site is easily accessible by the Kota Tinggi, Mersing road and a forest road. The forest reserve was gazetted as a Reserve on 8 November 1951 and lies around latitude $1^{\circ} 55^{\prime} \mathrm{N}$ and longitude $103^{\circ} 45^{\prime} \mathrm{E}$. The forest, with an area of $4806 \mathrm{ha}$, comprises 30 compartments or forest management units (FMUs). The average elevation of the forest reserve is about $300 \mathrm{~m}$ above sea level and the mean annual rainfall recorded at the nearest rainfall station averages $2480 \mathrm{~mm}$ (Lim and Chin, 1995). After preliminary survey for species abundance and logging schedule, Compartment 118, which is a virgin jungle, was selected for the study. This compartment is part of the Genetic Resource Area (GRA) Project in the Ulu Sedili Forest Reserve. The GRA project is a joint project between the Forestry Department of Peninsular Malaysia (FDPM), Johor State Forestry Department (JSFD) and the ASEAN Forest Seed Centre

Table 1

Details of the selected study sites in Peninsular Malaysia

\begin{tabular}{|c|c|c|c|}
\hline & \multicolumn{3}{|l|}{ Forest reserve } \\
\hline & Ulu Sedili Forest Reserve & Serting Tambahan Forest Reserve & Panti Forest Reserve \\
\hline Compartment & 118 & $48^{\mathrm{a}}$ & 69 \\
\hline Treatment $^{\mathrm{b}}$ & $\begin{array}{l}\text { Immediate effects of logging } \\
\text { (comparison between BF-C118 } \\
\text { and AF-C118) }\end{array}$ & $\begin{array}{l}\text { Short-term effects of logging } \\
(2.5 \text { years after logging) (comparison } \\
\text { between BF-C } 48 \text { and LS-C48) }\end{array}$ & $\begin{array}{l}\text { Long-term effects of logging } \\
\text { (about } 50 \text { years after logging) } \\
\text { (comparison between BF-C118 } \\
\text { and RS-C69) }\end{array}$ \\
\hline Total area (ha) & 164.3 & 139.0 & 271.2 \\
\hline Harvesting system & Selective management system (SMS) & SMS & Malayan Uniform System (MUS) \\
\hline Logging activity & August-December 2000 & Late $1995-1996$ & $1942-1950 \mathrm{~s}$ \\
\hline $\begin{array}{l}\text { Commonest tree } \\
\text { family }\end{array}$ & $\begin{array}{l}\text { Dipterocarpaceae, Myrtaceae, } \\
\text { Annonaceae, Lauraceae, Myristicaceae }\end{array}$ & $\begin{array}{l}\text { Euphorbiaceae, Annonaceae, } \\
\text { Burseraceae, Ebenaceae, Lauraceae }\end{array}$ & $\begin{array}{l}\text { Myrtaceae, Burseraceae, } \\
\text { Dipterocarpaceae, Lauraceae, } \\
\text { Myristicaceae }\end{array}$ \\
\hline
\end{tabular}

${ }^{a}$ The pre-felling (BF-C48) inventory data was provided by the Biodiversity Division, Forest Research Institute Malaysia (FRIM).

b BF-C118 = before logging, Compartment 118; AF-C118 = immediately after logging, Compartment 118; BF-C48 = before logging, Compartment 48; LS-C48 = logged stand (2.5 years after logging), Compartment 48; RS-C69 = regenerated stand (about 50 years after logging), Compartment 69. 
(AFTSC). The size of the Compartment 118 is about 164.3 ha with the elevation ranging from 120 to $1000 \mathrm{~m}$ above sea level. The most commonly occurring tree species in the compartment belong to the families Dipterocarpaceae, Myrtaceae, Annonaceae and Lauraceae. The SMS was employed in this compartment, i.e. the prescribed cutting limit for all commercial trees in the compartment was not less than $60 \mathrm{~cm} \mathrm{dbh}$ for dipterocarp tree species and not less than $50 \mathrm{~cm}$ dbh for non-dipterocarp tree species. This general prescribed cutting limit was determined based on the data from pre-felling inventory carried out before the logging operation. All trees to be felled were marked before harvesting. The availability of young regenerants in a particular logging regime and the genetic quality of the residuals left behind in the post-harvest stands are not specifically considered. Logging operation was carried out from August to December 2000 and about 4.55 ha, or $2.8 \%$ of the compartment, were cleared for skid roads and loglanding sites prior to the logging operation.

Serting Tambahan F.R. is a ridge forest located in Batu Kikir, Negeri Sembilan, Malaysia at $2^{\circ} 50^{\prime} \mathrm{N}$ latitude and $102^{\circ} 15^{\prime} \mathrm{E}$ longitude. Two compartments, which are virgin jungles, were selected for the study, viz. Compartment 40 (as unlogged stand) and Compartment 48 (a 2.5-year logged stand). These two compartments are located about $3 \mathrm{~km}$ from each other. The size of Compartment 40 is about 182.5 ha with the elevation ranging from 300 to $600 \mathrm{~m}$ above sea level. This compartment was not logged because of poor logging stock based on the pre-felling inventory data. Meanwhile, part of the compartment was used to construct the logging road for the logging operations in nearby compartments. A few big trees of probably $S$. curtisii nearby the study plot road were felled. The most commonly occurring tree species in this compartment belong to the families Myrtaceae, Meliaceae, Lauraceae and Dipterocarpaceae. Compartment 48 was identified for logging in late 1995 with logging being completed in late 1996 . The size of the compartment is about 139.9 ha with the elevation ranging from 400 to $700 \mathrm{~m}$ above sea level and the most commonly occurring tree species in the compartment belong to the families Euphorbiaceae, Burseraceae, Annonaceae, and Lauraceae. The SMS was practised, i.e. the prescribed cutting limit for all commercial trees in the compartment was not less than
$50 \mathrm{~cm} \mathrm{dbh}$ for dipterocarp tree species and not less than $45 \mathrm{~cm} \mathrm{dbh}$ for non-dipterocarp tree species. The minimum felling size is determined based on information on tree stocking prior to harvesting. All trees to be felled were marked before the logging operation. About 3.35 ha, or $2.4 \%$ of the compartment, were cleared for skid roads and log-landing sites prior to the logging operation.

Panti F.R. is located in Kota Tinggi, Johor, Malaysia at $1^{\circ} 52^{\prime} \mathrm{N}$ latitude and $103^{\circ} 53^{\prime} \mathrm{E}$ longitude. After preliminary survey of the compartments for species abundance and logging schedule, Compartment 69, which is a regenerated stand, was selected for the study. The size of the compartment is about 271.2 ha with the elevation ranging from 60 to $600 \mathrm{~m}$ above sea level. The most commonly occurring tree species in the compartment belong to the families Dipterocarpaceae, Myrtaceae, Burseraceae and Lauraceae. Logging operation was carried out from 1942 to 1950s under the Malayan Uniform System (MUS), i.e. all commercial trees not less than $45 \mathrm{~cm}$ dbh are allowed to be logged if there is sufficient regeneration of the species on the forest floor. If stocking is inadequate, the stand is to be left behind until after a seed year to be followed by another sampling. The system was designed for a 55-year rotation (WyattSmith, 1963; Thang, 1987). It was calculated that this was the period required for a Shorea (meranti) sapling to attain the desired size of $45 \mathrm{~cm} \mathrm{dbh}$.

\subsection{Demography survey}

Demographic data on number of trees, species and diameter of all trees above $1 \mathrm{~cm}$ dbh were measured and tagged from six $20 \mathrm{~m} \times 50 \mathrm{~m}$ ecological plots established at different elevations in Compartment 118 in August 1999 in Ulu Sedili F.R. During the postfelling inventory in April 2001 (after 3 months of logging), only three demographic plots, viz. plots 4,5 and 6 were enumerated. This was due to a landslide in the middle of the main logging road to demographic plots 1, 2 and 3. Thus, only the three demographic plots mentioned above were used to assess the direct immediate effects of logging on forest structure in Compartment 118. Meanwhile, three $20 \mathrm{~m} \times 50 \mathrm{~m}$ ecological plots were established at different elevations in Compartment 48 (June 1995) and Compartment 40 (December 1998), respectively, in Serting 
Tambahan F.R., and in regenerated stand of Compartment 69 (March 2000) in Panti F.R. The post-felling inventory for Compartment 48 was carried out after 2 years of logging, i.e. in April 1998 with the help of foresters from the Biodiversity Division of the Forest Research Institute Malaysia (FRIM). The demographic data was then used to estimate the short-term relative level of disturbance in Compartment 48 in comparison to Compartment 40 (unlogged stand) as well as to assess the direct short-term effects of logging on forest structure in Compartment 48. In Panti F.R., the demographic data was used to estimate the long-term relative level of disturbance of Compartment 69 (after about 50 years of logging) in comparison to Compartment 118 before logging.

\subsection{Demographic data analysis}

Parameters calculated include basal area per unit area $\left(\mathrm{m}^{2} \mathrm{ha}^{-1}\right)$, tree density per unit area, basal area and number of trees by dbh class and species richness (cumulative number of species based on scientific names or native names). Demographic data were then classified into 10 classes according to dbh, i.e. $<5 \mathrm{~cm}$ (seedlings and saplings), 5-15 cm (poles), $15-30 \mathrm{~cm}$ (small trees), $30-45 \mathrm{~cm}$ (medium trees), $45-60 \mathrm{~cm}$, $60-75 \mathrm{~cm}, 75-90 \mathrm{~cm}, 90-105 \mathrm{~cm}, 105-120 \mathrm{~cm}$ and $>120 \mathrm{~cm}$. Trees more than $45 \mathrm{~cm}$ dbh are considered as large trees and the further classification of diameter class of $>45 \mathrm{~cm} \mathrm{dbh}$ are to verify the status of the forest. All calculations and sorting of data were performed using Microsoft Excel worksheets. Eight demographic parameters were determined for each species in all the study plots using the formula described by Narayanan and Swarupanandan (1996):

Basal area $(\mathrm{BA})=\frac{\mathrm{dbh}^{2}}{4 \pi}$

Tree density $(\mathrm{TD})=\frac{\text { number of trees }}{\text { area }}$

Relative dominance (RBA)

$$
=\frac{\text { basal area of species } a}{\text { total basal area of all species }} \times 100
$$

Relative density (RD)

$$
=\frac{\text { no. individual of species } a}{\text { total individuals of all species }} \times 100
$$

Relative frequency $(\mathrm{RF})$

$$
=\frac{\text { frequency of species } a}{\text { sum of frequency values for all species }} \times 100
$$

Importance value index (IVI)

$$
=\mathrm{RBA}+\mathrm{RD}+\mathrm{RF}
$$

Relative importance value index (RIVI)

$$
=\frac{\text { importance value index }}{3}
$$

To estimate the relative disturbance index (RDI), IVI of each species were calculated. The RIVI for each species was determined from the IVI of each species. The range of the RIVI calculated for each species was divided into 10 equal classes and assigned a climax adaptation index (AI) of 1 for the lowest class and 10 for the highest class in order of increasing magnitude (Brown and Curtis, 1952). The ecological interpretation of AI is that, if you sat on a newly cleared area, you would see a sequence of trees appearing in the order of their climax adaptation numbers. The product of RIVI and the corresponding AI were summed for all the species in each plot to determine the continuum index (CI) (Curtis and McIntosh, 1951). CI is based on the concepts of succession and climax, and enables the stands to be ordered on a linear scale. The linear ordering also reflects the successional position of the stands and denotes the role of environment and the extent of disturbance on a site. The CI for the studied plots was arranged in order of increasing magnitude. An index for the level of disturbance (RDI) was assigned for each plot based on the relative differences in magnitude of CI. The plot with lowest CI was given an index of 1 and the others were determined based on the relative differences in CI. Smaller CI indicates a relatively lower level of disturbance (Narayanan and Swarupanandan, 1996).

Non-parametric statistics were used to find out whether there was any significant difference in the values of basal areas or tree densities between compartments for before and after logging in the same compartment. Kruskal-Wallis (KW) test was used for two sample comparisons in this study. All of the above analyses were performed using the SPSS 6.0 (Norusis, 1993) computer program. The demographic data of Compartment 48 was also analysed to determine the direct short-term effects of logging 
on basal area, tree density and spatial dispersion patterns of S. curtisii. Morisita's index of dispersion (Morisita, 1959) was calculated for S. curtisii from demographic plot 2 in Compartment 48, Serting Tambahan Forest Reserve. The Morisita's index was not calculated for demographic plots 1 and 3 due to insufficient sample size for $S$. curtisii in the demographic plot. The index is given by the formula:

$I_{\mathrm{d}}=\frac{n \sum X^{2}-N}{N(N-1)}$

where $n$ is the number of quadrats, $N$ the total number of individuals observed and $\sum X^{2}$ the squares of the numbers of individuals per quadrat, summed over all quadrats. The $\chi^{2}=\left[\left(n \sum X^{2} / N\right)-N\right]$ was used to test for the significance of the departure from a random distribution shown by the index. The index is 1 for random dispersion patterns, 0 for uniformity and $>1$ for aggregated or clumped populations.

\section{Results}

\subsection{Immediate effects of logging on forest structure in Ulu Sedili F.R.}

The mean basal area (for trees $\geq 1 \mathrm{~cm} \mathrm{dbh}$ ) in Compartment 118 before logging based on six and three demographic plots was $39.25 \pm 3.68$ and 33.66

Table 2

Mean basal area and tree density of trees $\geq 1 \mathrm{~cm} \mathrm{dbh}$ in four compartments in Peninsular Malaysia

\begin{tabular}{lll}
\hline Parameter & $\begin{array}{l}\text { Basal area } \\
\left(\mathrm{m}^{2} \mathrm{ha}^{-1}\right) \pm \text { S.E. }\end{array}$ & $\begin{array}{l}\text { Tree density } \\
\left(\mathrm{ha}^{-1}\right) \pm \text { S.E. }\end{array}$ \\
\hline $\begin{array}{l}\text { Compartment 118 } \\
\text { BF-C118(6) })^{\mathrm{a}}\end{array}$ & $39.23 \pm 3.68$ & $3578 \pm 480$ \\
$\quad$ BF-C118 & $33.66 \pm 1.57$ & $3507 \pm 940$ \\
AF-C118 & $17.48 \pm 5.39$ & $1874 \pm 254$ \\
Compartment 48 & & \\
$\quad$ BF-C48 & $49.86 \pm 5.90$ & $4197 \pm 257$ \\
$\quad$ LS-C48 & $25.24 \pm 3.84$ & $3440 \pm 430$ \\
$\begin{array}{l}\text { Compartment 40 } \\
\text { UL-C40 }\end{array}$ & $34.24 \pm 9.83$ & \\
Compartment 69 & & $1274 \pm 360$ \\
$\quad$ RS-C69 & $32.58 \pm 2.37$ & $3950 \pm 981$ \\
\hline
\end{tabular}

${ }^{\text {a }}$ BF-C118(6) = before logging, Compartment 118 (based on six ecological plots).

${ }^{\mathrm{b}}$ UL-C40 = unlogged stand, Compartment 40. $\pm 1.57 \mathrm{~m}^{2} \mathrm{ha}^{-1}$, respectively, in Ulu Sedili F.R. The difference between mean basal areas based on six or three demographic plots was only $14.2 \%$ (Table 2 ). The mean basal area after logging (based on three demographic plots, viz. plots 4, 5 and 6) was $17.48 \pm$ $5.39 \mathrm{~m}^{2} \mathrm{ha}^{-1}$, i.e. a significant reduction of $48.1 \%$ (KW test, $P<0.05$ ) with the largest diameter class ( $>45 \mathrm{~cm} \mathrm{dbh)} \mathrm{being} \mathrm{most} \mathrm{affected} \mathrm{(Table} 3$ ) as these were the trees that were chosen for felling. The area cleared for logging roads, skid trials and log-landing sites was 4.55 ha or $2.8 \%$. Hence, the total reduction of mean basal area (for trees $\geq 1 \mathrm{~cm} \mathrm{dbh}$ ) based on three demographic plots in Compartment 118 after logging was $50.9 \%$. This value is rather conservative because the total reduction of mean basal area after logging based on six demographic plots was 58.2\%. Mean tree density (for trees $\geq 1 \mathrm{~cm} \mathrm{dbh)} \mathrm{after} \mathrm{logging} \mathrm{was}$ decreased by $46.6 \%$, i.e. from 3507 to 1873 trees (Table 2). All large trees more than $60 \mathrm{~cm}$ dbh were felled in a single selective logging event (Table 3) under the prescribed cutting limits by the Forestry Department, Johor. The mean basal area and tree density for seedling and sapling diameter class $(<5 \mathrm{~cm} \mathrm{dbh})$ after logging were reduced to about half of the original stand (Table 3). For dipterocarp species, the mean basal area (for trees $\geq 1 \mathrm{~cm} \mathrm{dbh}$ ) was 11.53 and $3.87 \mathrm{~m}^{2} \mathrm{ha}^{-1}$ before and after logging (Table 4), respectively. There was a significant reduction of $66.4 \%$ (KW test, $P<0.05$ ) with the largest diameter class $(>45 \mathrm{~cm} \mathrm{dbh})$ being most affected $(42.8 \%)$. The mean tree density (for trees $\geq 1 \mathrm{~cm} \mathrm{dbh)} \mathrm{was} \mathrm{decreased} \mathrm{by} 49.2 \%$, i.e. from 604 to 307 trees after logging (Table 4). The seedling and sapling diameter class $(<5 \mathrm{~cm}$ dbh $)$ was wellrepresented before and after logging, contributing $64.1 \%$ and $60.9 \%$ of the total tree density, respectively, in Compartment 118 (Table 5).

Species richness before and after logging in the three ecological plots was variable within narrow limits with no clear difference (Table 6). When the three demographic plots for before and after logging were pooled, the total number of families was 33 and 30 , respectively. Meanwhile, based on the native name, the total number of species observed was 89 and 72 , respectively, for before and after logging. The commonly occurring families in the before and after logging plots were unchanged, i.e. Dipterocarpaceae, Myrtaceae, Annonaceae, Lauraceae and Myristica- 
Table 3

Mean basal area per hectare $\left(\mathrm{BA}, \mathrm{m}^{2} \mathrm{ha}^{-1}\right)$ and tree density $\left(\mathrm{TD}, \mathrm{ha}^{-1}\right)$ by dbh in four compartments in Peninsular Malaysia

\begin{tabular}{|c|c|c|c|c|c|c|c|c|c|c|c|}
\hline & \multicolumn{11}{|l|}{ dbh classes $(\mathrm{cm})$} \\
\hline & $<5$ & $5-15$ & $15-30$ & $30-45$ & $45-60$ & $60-75$ & $75-90$ & $90-105$ & $105-120$ & $>120$ & Total \\
\hline \multicolumn{12}{|l|}{ Compartment 118} \\
\hline \multicolumn{12}{|l|}{ BF-C118 } \\
\hline BA $\left(\mathrm{m}^{2} \mathrm{ha}^{-1}\right)$ & $1.38(0.41)$ & $5.04(0.77)$ & $8.50(1.01)$ & $10.17(0.61)$ & $4.79(1.39)$ & $2.02(2.02)$ & $1.76(1.76)$ & $0.00(0.00)$ & $0.00(0.00)$ & $0.00(0.00)$ & $33.66(1.57)$ \\
\hline $\mathrm{TD}\left(\mathrm{ha}^{-1}\right)$ & $2317(821)$ & $837(153)$ & $227(35)$ & $93(7)$ & $23(7)$ & $7(7)$ & $3(3)$ & $0(0)$ & $0(0)$ & $0(0)$ & 3507 (940) \\
\hline \multicolumn{12}{|l|}{ AF-C48 } \\
\hline $\mathrm{BA}\left(\mathrm{m}^{2} \mathrm{ha}^{-1}\right)$ & $0.69(0.17)$ & $3.19(0.59)$ & $6.03(2.83)$ & $6.21(2.77)$ & $1.36(0.68)$ & $0.00(0.00)$ & $0.00(0.00)$ & $0.00(0.00)$ & $0.00(0.00)$ & $0.00(0.00)$ & 17.48 \\
\hline TD $\left(\mathrm{ha}^{-1}\right)$ & $1113(246)$ & $537(98)$ & $160(82)$ & $57(29)$ & $7(3)$ & $0(0)$ & $0(0)$ & $0(0)$ & $0(0)$ & $0(0)$ & $1874(254)$ \\
\hline \multicolumn{12}{|l|}{ Compartment 48} \\
\hline \multicolumn{12}{|l|}{ BF-C48 } \\
\hline BA $\left(\mathrm{m}^{2} \mathrm{ha}^{-1}\right)$ & $1.11(0.03)$ & $5.10(0.37)$ & $11.00(1.02)$ & 7.86 (1.13) & $7.08(3.09)$ & $6.76(1.87)$ & 3.47 (1.78) & $2.34(2.34)$ & $0.00(0.00)$ & $5.15(5.15)$ & $49.86(5.90)$ \\
\hline $\mathrm{TD}\left(\mathrm{ha}^{-1}\right)$ & $2893(260)$ & $846(34)$ & $316(35)$ & $76(12)$ & $33(14)$ & $20(6)$ & $7(3)$ & $3(3)$ & $0(0)$ & $3(3)$ & 4197 (257) \\
\hline \multicolumn{12}{|l|}{ LS-C48 } \\
\hline BA $\left(\mathrm{m}^{2} \mathrm{ha}^{-1}\right)$ & $1.38(0.19)$ & $4.35(0.65)$ & $6.62(1.00)$ & $5.46(1.12)$ & $4.42(2.34)$ & $3.01(0.11)$ & $0.00(0.00)$ & $0.00(0.00)$ & $0.00(0.00)$ & $0.00(0.00)$ & $25.24(3.87)$ \\
\hline TD $\left(\mathrm{ha}^{-1}\right)$ & $2473(346)$ & $687(75)$ & $193(8)$ & $53(12)$ & $23(13)$ & $10(6)$ & $0(0)$ & $0(0)$ & $0(0)$ & $0(0)$ & $3440(430)$ \\
\hline \multicolumn{12}{|l|}{ Compartment 40} \\
\hline $\mathrm{TD}\left(\mathrm{ha}^{-1}\right)$ & $573(248)$ & $450(83)$ & $127(35)$ & $67(18)$ & $27(13)$ & $20(12)$ & $7(7)$ & $0(0)$ & $3(3)$ & $0(0)$ & $1274(360)$ \\
\hline \multicolumn{12}{|l|}{ Compartment 69} \\
\hline \multicolumn{12}{|l|}{ RS-C69 } \\
\hline BA $\left(\mathrm{m}^{2} \mathrm{ha}^{-1}\right)$ & $1.76(0.56)$ & $4.99(0.87)$ & $4.46(0.67)$ & $8.24(0.69)$ & $4.82(1.85)$ & $3.63(2.07)$ & $1.51(1.51)$ & $0.00(0.00)$ & $3.17(3.17)$ & $0.00(0.00)$ & $32.58(2.37)$ \\
\hline $\mathrm{TD}\left(\mathrm{ha}^{-1}\right)$ & $2793(805)$ & $897(185)$ & $140(26)$ & $77(3)$ & $27(12)$ & $10(6)$ & $3(3)$ & $0(0)$ & $3(3)$ & $0(0)$ & 3950 (981) \\
\hline
\end{tabular}


Table 4

Mean basal area and tree density (for trees $\geq 1 \mathrm{~cm} \mathrm{dbh}$ ) of dipterocarp (Dipt.) and non-dipterocarp (non-Dipt.) species in four compartments in Peninsular Malaysia

\begin{tabular}{|c|c|c|c|c|}
\hline \multirow[t]{2}{*}{ Parameter } & \multicolumn{2}{|c|}{ Basal area $\left(\mathrm{m}^{2} \mathrm{ha}^{-1}\right)(\%$ of total $)$} & \multicolumn{2}{|c|}{ Tree density $\left(\right.$ ha $\left.^{-1}\right)(\%$ of total $)$} \\
\hline & Dipt. (\%) & Non-Dipt. (\%) & Dipt. (\%) & Non-Dipt. (\%) \\
\hline \multicolumn{5}{|c|}{ Compartment 118} \\
\hline BF-C118 & $11.53(34.3)$ & $22.12(65.7)$ & $604(17.2)$ & $2903(82.8)$ \\
\hline AF-C118 & $3.88(22.2)$ & $13.60(77.8)$ & $307(16.4)$ & 1567 (83.6) \\
\hline \multicolumn{5}{|c|}{ Compartment 48} \\
\hline BF-C48 & $9.24(18.5)$ & $40.62(81.5)$ & 248 (5.9) & $3949(94.1)$ \\
\hline LS-C48 & $2.24(8.9)$ & $23.00(91.1)$ & $138(4.0)$ & $3302(96.0)$ \\
\hline \multicolumn{5}{|c|}{ Compartment 40} \\
\hline UL-C40 & $2.37(6.9)$ & $31.87(93.1)$ & $61(4.8)$ & $1213(95.2)$ \\
\hline \multicolumn{5}{|c|}{ Compartment 69} \\
\hline RS-C69 & $4.50(13.8)$ & $28.08(86.2)$ & $376(9.5)$ & $3574(90.5)$ \\
\hline
\end{tabular}

Table 5

Mean basal area (BA, $\mathrm{m}^{2} \mathrm{ha}^{-1}$ ), mean tree density $\left(\mathrm{TD}, \mathrm{ha}^{-1}\right.$ ) and species number by dbh of dipterocarp species in four compartments in Peninsular Malaysia

\begin{tabular}{|c|c|c|c|c|c|c|}
\hline & \multicolumn{6}{|c|}{ dbh classes $(\mathrm{cm})$} \\
\hline & $<5$ & $5-15$ & $15-30$ & $30-45$ & $>45$ & Total \\
\hline \multicolumn{7}{|l|}{ Compartment 118} \\
\hline \multicolumn{7}{|l|}{ BF-C118 } \\
\hline BA $\left(\mathrm{m}^{2} \mathrm{ha}^{-1}\right)$ & 0.20 & 1.03 & 1.72 & 3.64 & 4.94 & 11.53 \\
\hline $\mathrm{TD}\left(\mathrm{ha}^{-1}\right)$ & 387 & 130 & 40 & 30 & 17 & 604 \\
\hline No. of species & 21 & 14 & 9 & 5 & 5 & 21 \\
\hline \multicolumn{7}{|l|}{ AF-C118 } \\
\hline BA $\left(\mathrm{m}^{2} \mathrm{ha}^{-1}\right)$ & 0.11 & 0.70 & 0.90 & 2.17 & 0.00 & 3.88 \\
\hline $\mathrm{TD}\left(\mathrm{ha}^{-1}\right)$ & 187 & 80 & 23 & 17 & 0 & 307 \\
\hline No. of species & 17 & 9 & 6 & 3 & 0 & 19 \\
\hline \multicolumn{7}{|l|}{ Compartment 48} \\
\hline \multicolumn{7}{|l|}{ BF-C48 } \\
\hline BA $\left(\mathrm{m}^{2} \mathrm{ha}^{-1}\right)$ & 0.04 & 0.34 & 0.79 & 1.92 & 6.15 & 9.24 \\
\hline TD $\left(\mathrm{ha}^{-1}\right)$ & 147 & 50 & 27 & 17 & 7 & 248 \\
\hline No. of species & 7 & 5 & 4 & 2 & 2 & 10 \\
\hline \multicolumn{7}{|l|}{ LS-C48 } \\
\hline BA $\left(\mathrm{m}^{2} \mathrm{ha}^{-1}\right)$ & 0.02 & 0.17 & 0.54 & 1.51 & 0.00 & 2.24 \\
\hline $\mathrm{TD}\left(\mathrm{ha}^{-1}\right)$ & 80 & 24 & 20 & 14 & 0 & 138 \\
\hline No. of species & 6 & 5 & 2 & 3 & 0 & 8 \\
\hline \multicolumn{7}{|l|}{ Compartment 40} \\
\hline \multicolumn{7}{|l|}{ UL-C40 } \\
\hline BA $\left(\mathrm{m}^{2} \mathrm{ha}^{-1}\right)$ & 0.02 & 0.06 & 0.40 & 0.48 & 1.41 & 2.37 \\
\hline $\mathrm{TD}\left(\mathrm{ha}^{-1}\right)$ & 30 & 10 & 10 & 4 & 7 & 61 \\
\hline No. of species & 2 & 2 & 1 & 1 & 2 & 3 \\
\hline \multicolumn{7}{|l|}{ Compartment 69} \\
\hline \multicolumn{7}{|l|}{ RS-C69 } \\
\hline BA $\left(\mathrm{m}^{2} \mathrm{ha}^{-1}\right)$ & 0.21 & 0.22 & 0.44 & 0.46 & 3.17 & 4.50 \\
\hline $\mathrm{TD}\left(\mathrm{ha}^{-1}\right)$ & 307 & 47 & 14 & 4 & 4 & 376 \\
\hline No. of species & 12 & 5 & 3 & 1 & 1 & 13 \\
\hline
\end{tabular}


Table 6

Family and species number in four compartments in Peninsular Malaysia

\begin{tabular}{|c|c|c|}
\hline \multicolumn{3}{|c|}{ No. of families No. of species $(B)^{\mathrm{a}}$ No. of species $(N)^{\mathrm{b}}$} \\
\hline \multicolumn{3}{|c|}{ Compartment 118} \\
\hline \multicolumn{3}{|c|}{ BF-C118 } \\
\hline Plot 428 & - & 71 \\
\hline Plot 527 & - & 51 \\
\hline Plot 620 & - & 35 \\
\hline Pooled 33 & & 89 \\
\hline \multicolumn{3}{|l|}{$\mathrm{AF}-\mathrm{C} 118$} \\
\hline Plot 422 & - & 44 \\
\hline Plot 524 & - & 43 \\
\hline Plot 619 & - & 33 \\
\hline Pooled 30 & - & 72 \\
\hline \multicolumn{3}{|l|}{ Compartment 48} \\
\hline \multicolumn{3}{|c|}{ BF-C48 } \\
\hline Plot 140 & 145 & 85 \\
\hline Plot 238 & 155 & 89 \\
\hline Plot 443 & 168 & 102 \\
\hline Pooled 53 & 304 & 136 \\
\hline \multicolumn{3}{|l|}{ LS-C48 } \\
\hline Plot 140 & 146 & 75 \\
\hline Plot 238 & 154 & 73 \\
\hline Plot 443 & 169 & 92 \\
\hline Pooled 53 & 303 & 134 \\
\hline \multicolumn{3}{|c|}{ Compartment 40} \\
\hline \multicolumn{3}{|c|}{ UL-C40 } \\
\hline Plot 120 & - & 29 \\
\hline Plot 218 & - & 31 \\
\hline Plot 312 & - & 16 \\
\hline Pooled 24 & - & 49 \\
\hline \multicolumn{3}{|c|}{ Compartment 69} \\
\hline \multicolumn{3}{|c|}{ RS-C69 } \\
\hline Plot 121 & - & 30 \\
\hline Plot 225 & - & 41 \\
\hline Plot 324 & - & 33 \\
\hline Pooled 35 & - & 64 \\
\hline
\end{tabular}

${ }^{\text {a }}$ No. of species $(B)=$ No. of species based on botanical name.

b No. of species $(N)=$ No. of species based on native name.

ceae. The number of dipterocarp species by diameter class before and after logging in Compartment 118 was only marginally different except for $>45 \mathrm{~cm}$ dbh class (Table 5). The commonest species, in terms of density was Dryobalanops aromatica, Shorea laevis, Shorea macroptera, Hopea sp. and Shorea pauciflora.

Relationship between tree density (TD) and basal area per hectare (BA) with relative disturbance indices (RDI) was carried out based on the local name by the
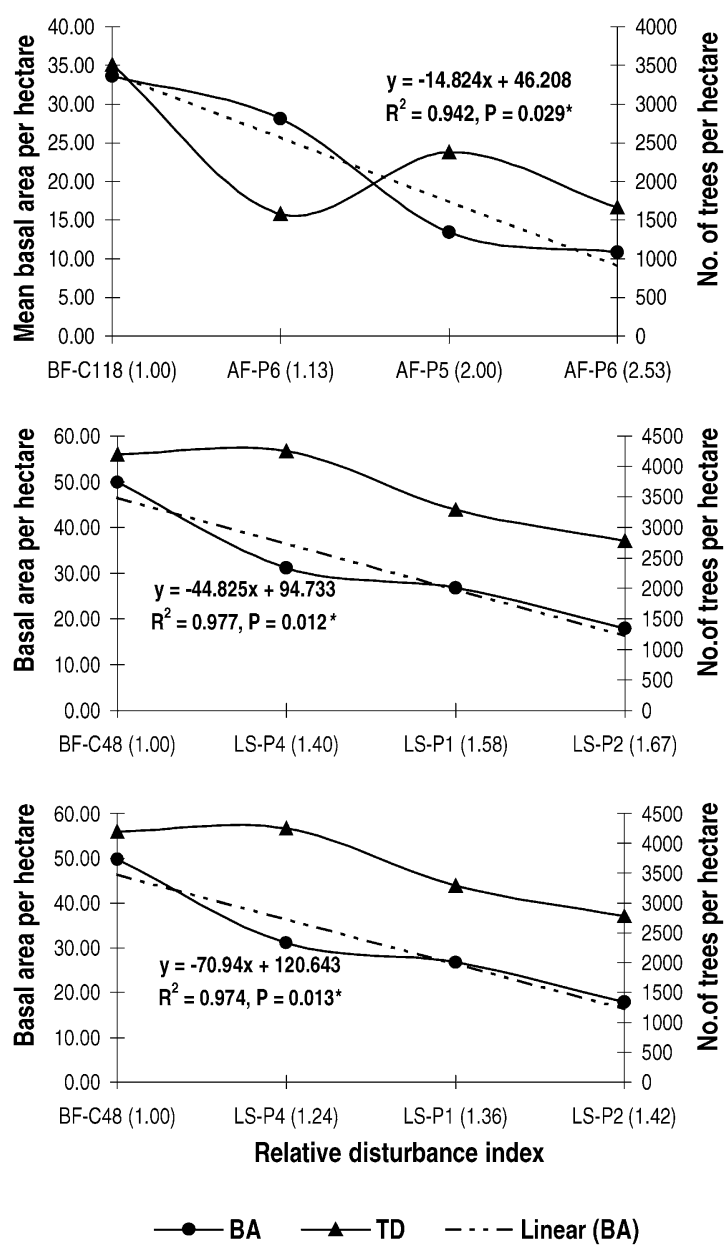

Fig. 1. Relationship between tree density per hectare (TD) and mean basal area per hectare (BA) with increasing relative disturbance index (RDI): (a) Compartment 118, based on native name ( $r=$ $-0.971, P=0.029$ ); (b) Compartment 48 , based on botanical name $(r=-0.988, P=0.012)$; and (c) Compartment 48, based on native name $(r=-0.987, P=0.013)$.

foresters from Forestry Department, Johor. BA was negatively correlated with RDI $(r=-0.971, P=$ 0.029) for the Compartment 118 after logging (Fig. 1a). In contrast, TD was not significantly correlated with RDI. The negative correlation between $\mathrm{BA}$ and RDI shows that the relative disturbance for the different plots followed the principle of continuum index (CI). CI was lowest (154.75) before logging in Compartment 118 (BF-118) and highest (403.65) after logging in plot 4 (AF-P4) (Table 7). According to Narayanan and Swarupanandan (1996), smaller CI 
Table 7

Continuum index (CI), relative disturbance index (RDI), percentage of disturbance based on mean basal area per hectare (\%Dtb) and field observation for the different plots in Compartments 118 and 48 based on botanical or native name

\begin{tabular}{lrrll}
\hline Plot & CI & RDI & \%Dtb & Field observation \\
\hline $\begin{array}{l}\text { Compartment } \\
\text { 118 }\end{array}$ & (based on native name) & & \\
BF-C118 & 154.75 & 1.00 & 0.00 & No disturbance \\
AF-P6 & 173.28 & 1.13 & 12.92 & Low intensity selective logging \\
AF-P5 & 314.36 & 2.00 & 63.55 & Low intensity selective logging, logging road \\
AF-P4 & 403.65 & 2.53 & 65.87 & Low intensity selective logging, logging road, skid trails \\
Compartment & & & \\
BF-C48 & 203.91 & 1.00 & 0.00 & No disturbance \\
AF-P4 & 285.15 & 1.40 & 34.76 & Low intensity selective logging \\
AF-P1 & 322.02 & 1.58 & 56.16 & Low intensity selective logging and skid trials \\
AF-P2 & 339.37 & 1.67 & 56.30 & Low intensity selective logging, skid trials and low intense fire \\
Compartment & & & \\
BF-C48 & (based on native name) & & & \\
AF-P4 & 287.73 & 1.00 & 0.00 & No disturbance \\
AF-P1 & 357.57 & 1.24 & 34.76 & Low intensity selective logging \\
AF-P2 & 392.80 & 1.36 & 56.16 & Low intensity selective logging and skid trials \\
\hline
\end{tabular}

indicates a relatively lower level of disturbance. Regression analysis was performed based on general linear model (GLM) using Systat computer program to generate the regression line formula of RDI. The regression line formula for the basal area per hectare based on local name in Compartment 118 was:

$$
\begin{gathered}
Y=-14.824 x+46.208 \\
\quad\left(R^{2}=0.942, P=0.029\right)
\end{gathered}
$$

where $Y$ is the basal area per hectare and $x$ the particular degree of RDI values. There was no significant difference between the calculated RDI values and RDI values estimated using the above formula.

\subsection{Short-term effects of logging on forest structure in Serting Tambahan F.R.}

The mean basal area (for trees $\geq 1 \mathrm{~cm} \mathrm{dbh}$ ) in Compartment 48 before logging (BF-C48) was much higher than that in Compartment 40 or unlogged stand (UL-C40), Serting Tambahan F.R. This is mainly due to higher tree densities in Compartment 48 before logging. Based on the pre-felling inventory, the mean basal area of BF-C48 and UL-C40 were $49.86 \pm 5.90$ and $34.24 \pm 9.83 \mathrm{~m}^{2} \mathrm{ha}^{-1}$, respectively (Table 2). After 2.5 years of logging in Compartment 48 (LSC48), the mean basal area of the compartment was $25.24 \pm 3.87 \mathrm{~m}^{2} \mathrm{ha}^{-1}$, i.e. a significant reduction of
49.4\% (KW test, $P<0.05$ ) with the large tree

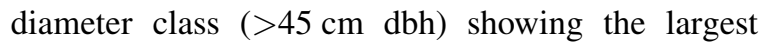
reduction (Table 3 ). The area cleared for skid roads and log-landing sites was 3.35 ha or $2.4 \%$ reduction of total vegetative covered in the compartment. Hence, the total reduction of mean basal area (for trees $\geq 1 \mathrm{~cm}$ $\mathrm{dbh}$ ) was about $51.8 \%$. However, according to Lee (1999), during the sampling of residuals after the logging operation was completed some burnt areas and vegetable farming were observed. The fire can kill the seedlings and saplings, and encourage the invasion of fire resistant species. Therefore, the 51.8\% reduction in basal area is a conservative estimate. Mean tree density (for trees $\geq 1 \mathrm{~cm}$ dbh) after logging in Compartment 48 was decreased by $18 \%$, i.e. from 4197 to 3440 trees (Table 2). All trees more than $75 \mathrm{~cm}$ dbh were removed in a single selective logging event. The mean tree density for the seedling and sapling diameter class $(<5 \mathrm{~cm} \mathrm{dbh})$ was decreased by $14.5 \%$ although there was increased in basal area (24.3\%) 2.5 years after logging (Table 3 ).

The proportion of dipterocarp species before logging in Compartment 48 was only $18.5 \%$ of the total basal area $\left(49.87 \mathrm{~m}^{2} \mathrm{ha}^{-1}\right)$. This was largely due to less abundance of dipterocarp species (248 out of 4201 trees). The mean basal area (for trees $\geq 1 \mathrm{~cm}$ $\mathrm{dbh}$ ) was reduced significantly by $75.8 \%$ (KW test, $P$ $<0.05)$ after logging with the largest diameter class $(>45 \mathrm{~cm} \mathrm{dbh)} \mathrm{constituting} \mathrm{of} 66.6 \%$ being most 
affected (Tables 4 and 5 ). The tree density $\left(\mathrm{ha}^{-1}\right.$ ) was decreased by $44.4 \% 2.5$ years after logging in Compartment 48. The dipterocarp species only contributed $6.9 \%$ or $4.9 \%$ of the total basal area or tree density in Compartment 40 . The mean basal area and tree density for seedling and sapling class $(<5 \mathrm{~cm}$ $\mathrm{dbh})$ and poles $(5-15 \mathrm{~cm} \mathrm{dbh})$ in Compartment 48 were reduced to about one-half of the original stand 2.5 years after logging (Table 5). These results indicate quite clearly that the smallest diameter class and large trees $(>45 \mathrm{~cm} \mathrm{dbh})$ of dipterocarp species were most affected during the logging operation.

There was no clear difference in species composition in the before and after logging plots in Compartment 48 (Table 6). The total number of families in Compartment 48 was unchanged 2.5 years after logging (53 families) across the demographic plots. For the respective plots, the total number of species based on botanical or native names was only marginally different after logging. The most commonly occurring families were similar before and 2.5 years after logging in Compartment 48, i.e. Euphorbiaceae, Annonaceae, Burseraceae, Ebenaceae and Lauraceae. Dipterocarpaceae was less dominant in Compartment 48. In Compartment 40, the total number of families and species based on native name was 24 and 49, respectively, across the three demographic plots. Of the 10 commonest families, in terms of tree density, in each of the three plots, five, viz. Myrtaceae, Meliaceae, Lauraceae, Dipterocarpaceae and Leguminosae were common to all three plots. The number of dipterocarp species by diameter class 2.5 years after logging in Compartment 48 varied but no significant difference was observed compared to before logging in Compartment 48 (Table 5). The commonest species, in terms of tree density, was S. curtisii, Vatica odorata and Shorea leprosula observed before and 2.5 years after logging in Compartment 48. In contrast, there were only three dipterocarp species observed in Compartment 40, i.e. S. curtisii, S. leprosula and S. laevis.

Relationship between TD and BA with RDI was carried out based on the botanical and native name of each species in the plots in Compartment 48 (Table 7). BA as in Compartment 118 was negatively correlated with RDI for the Compartment 48 after logging based on the botanical ( $r=-0.988, P=0.012)$ (Fig. 1b) and native name $(r=-0.987, P=0.013$ ) (Fig. 1c).
However, the RDI values were lower or underestimates based on native name. This is because one local name can be used for many tree species. In contrast, TD was not correlated with RDI values estimated based on botanical or native names. The respective regression formulas for basal area based on a general linear model (GLM) are:

Based on botanical name :

$$
\begin{aligned}
& Y=-44.825 x+94.733 \\
& \left(R^{2}=0.977, P=0.012\right)
\end{aligned}
$$

Based on native name :

$$
\begin{aligned}
& Y=-70.94 x+120.643 \\
& \left(R^{2}=0.974, P=0.013\right)
\end{aligned}
$$

where $Y$ is the basal area per hectare and $x$ the particular degree of relative disturbance index (RDI) values. The calculated RDI values based on native name were not significantly different from the RDI values estimated from botanical name. Moreover, there was no significant difference observed between calculated RDI values and RDI values estimated using above formula. This suggests that both formulae could be used to estimate RDI values in other compartments if basal area data are available. It should be noted that these formulae do not give anything more than an indication of the degree of the type and magnitude of disturbances in each of the localities in the forest. Indeed, it is improbable that anything more accurate could ever be given since there would always be variations due to stand, topography and experience of workers, which could vary the estimation of both CI and RDI values.

\subsection{Long-term effects of logging on forest structure in Panti F.R.}

The indirect comparison of long-term effects of logging (about 50 years after logging) was carried out between Compartment 118 before logging (BF-C118) as an unlogged stand in Ulu Sedili F.R. with the regenerated stand of Compartment 69 (RS-C69) in Panti F.R. The distance between the compartments is about $10 \mathrm{~km}$. The mean basal area (for trees $\geq 1 \mathrm{~cm}$ dbh) was only marginally different between BF-C118 
and RS-C69, i.e. 2.3\% lower at RS-C69 (Table 2). For seedling and sapling diameter class $(<5 \mathrm{~cm} \mathrm{dbh})$, the mean basal area in the RS-C69 was $28.5 \%$ more than that in BF-C118 meanwhile the small trees class (15$30 \mathrm{~cm}$ dbh) basal area was significantly less $(47.5 \%)$ than that in BF-C118 (Table 3). In terms of mean tree density, RS-C69 was $12.6 \%$ more compared to BFC118 (Table 2). This was largely due to a much higher density at the minimum size class $(<15 \mathrm{~cm} \mathrm{dbh})$. There were $20.5 \%$ and $7.2 \%$ more trees in the seedling and sapling diameter class $(<5 \mathrm{~cm} \mathrm{dbh})$ and in the pole diameter class $(5-15 \mathrm{~cm} \mathrm{dbh})$, respectively (Table 3).

Despite the large differences in basal area for the small tree class, the total basal area in both compartments was only marginally different. Thus, the lower basal area in the small tree class in RS-C69 was compensated for by the greater basal area contributed by the large number of trees in the smallest and largest size classes in the stand. Therefore, this site carrying capacity, in terms of basal area in a unit of forest, showed that any departure from this level caused by logging activities or other larger-scale disturbances sets in motion forces that tend to bring back this equilibrium (Manokaran, 1996). Movement towards equilibrium with respect to basal area in a unit of forest has been shown through long-term studies in primary dipterocarp forests by Manokaran and Swaine (1994). Thus, net loss in trees was offset by incremental growth in surviving trees. For dipterocarp species, the mean basal area (for trees $\geq 1 \mathrm{~cm} \mathrm{dbh}$ ) in RS-C69 was significantly less by $61.0 \%$ compared to that in BFC118. There were $37.7 \%$ less trees in RS-C69 compared to BF-C118 (Table 4). The seedling and sapling diameter class $(<5 \mathrm{~cm} \mathrm{dbh})$ was wellrepresented in RS-C69, contributing $81.6 \%$ of the total density, but not in the large diameter class ( $>30 \mathrm{~cm} \mathrm{dbh)} \mathrm{trees} \mathrm{(Table} \mathrm{5).}$

In terms of species composition, RS-C69 had slightly less species and families across plots than BFC118 (Table 6). The total number of families and species based on native names in RS-C69 were 35 and 64 , respectively. The most commonly occurring families in RS-C69 were Dipterocarpaceae, Myrtaceae, Lauraceae, Myristicaceae and Burseraceae. Species composition of dipterocarp species in RSC69 had slightly less species than that in BF-C118 (Table 5). When the three demographic plots were pooled, the total number of species in RS-C69 was 13 meanwhile in BF-C118, it was 21 , i.e. a $38.1 \%$ difference in species number. The commonest species observed in RS-C69 were Dipterocarpus verrucosus, S. macroptera, S. pauciflora, Hopea sp. and Shorea parvifolia.

\subsection{Demography survey of $S$. curtisii in Compartment 48 in Serting Tambahan F.R.}

The mean basal area (for trees $\geq 1 \mathrm{~cm} \mathrm{dbh}$ ) for $S$. curtisii before and 2.5 years after logging was 9.41 and $0.71 \mathrm{~m}^{2} \mathrm{ha}^{-1}$ (Table 8), respectively, in Compartment 48 , i.e. a significant reduction of $92.5 \%$ (KW test, $P<$ $0.05)$. The largest diameter class $(>45 \mathrm{~cm} \mathrm{dbh})$ was most affected, i.e. from 10 to 5 trees per hectare, as these were the stems that were chosen for felling. Moreover, $S$. curtisii is the main commercial timber species in ridge crests of hill dipterocarp forest. The biggest $S$. curtisii tree recorded in the demographic plot was $140.2 \mathrm{~cm}$ dbh and comprised $15.4 \mathrm{~m}^{2}$ in basal area. In terms of tree density, there was a $64.5 \%$ reduction in the number of $S$. curtisii trees per hectare (for tree $\geq 1 \mathrm{~cm} \mathrm{dbh)} 2.5$ years after logging in Compartment 48 . The tree density for poles $(5-15 \mathrm{~cm}$ $\mathrm{dbh})$ and small trees $(15-30 \mathrm{~cm} \mathrm{dbh})$ was most affected after a single selective logging operation. There was no S. curtisii tree in small tree diameter class observed 2.5 years after logging in Compartment 48 (Table 8). Therefore, in situations like this, selective cutting results in very unsatisfactory residual stocking. According to Fox (1967) and Wyatt-Smith (1988), there is poor representation of the middle sizes of trees in the Malaysian dipterocarp forests, but large trees, and small seedlings and saplings are well

Table 8

Mean basal area (BA, $\mathrm{m}^{2} \mathrm{ha}^{-1}$ ) and tree density (TD, ha ${ }^{-1}$ ) by dbh for $S$. curtisii in Compartment 48, Serting Tambahan F.R.

\begin{tabular}{|c|c|c|c|c|c|c|}
\hline & \multicolumn{6}{|c|}{ dbh classes $(\mathrm{cm})$} \\
\hline & $<5$ & $5-15$ & $15-30$ & $30-45$ & $>45$ & Total \\
\hline \multicolumn{7}{|l|}{ BF-C48 } \\
\hline BA $\left(\mathrm{m}^{2} \mathrm{ha}^{-1}\right)$ & 0.02 & 0.25 & 0.10 & 1.32 & 7.72 & 9.41 \\
\hline TD $\left(\mathrm{ha}^{-1}\right)$ & 95 & 40 & 5 & 10 & 5 & 155 \\
\hline \multicolumn{7}{|l|}{ LS-C48 } \\
\hline BA $\left(\mathrm{m}^{2} \mathrm{ha}^{-1}\right)$ & 0.01 & 0.02 & 0.00 & 0.68 & 0.00 & 0.71 \\
\hline TD $\left(\mathrm{ha}^{-1}\right)$ & 45 & 5 & 0 & 5 & 0 & 55 \\
\hline
\end{tabular}




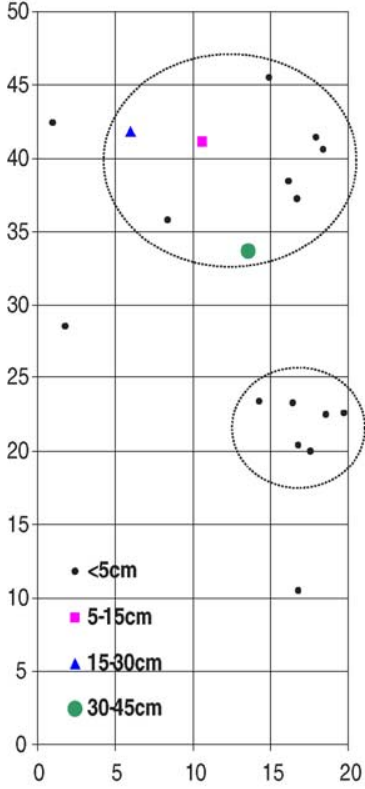

(a)

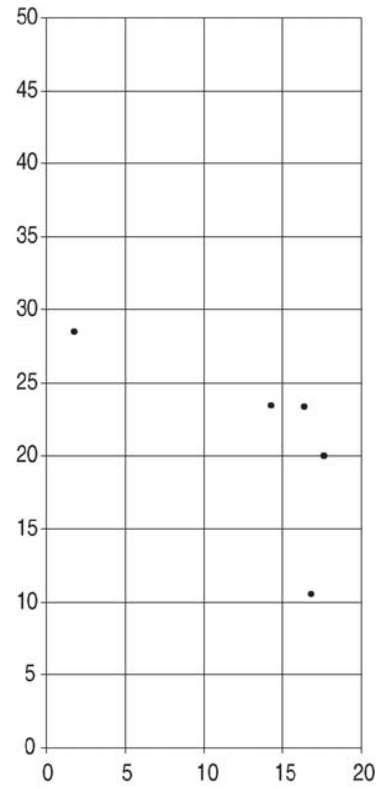

(b)
Fig. 2. Clumped distribution of $S$. curtisii in demographic plot 2, Compartment 48, Serting Tambahan F.R.: (a) plot 2, before logging (BF-C48); and (b) plot 2, after logging (AF-C48).

represented. The apparent success of the selective felling in Philippines is attributed to the abundance of the intermediate classes in the dipterocarp-rich forests (Walton, 1954). These intermediate-sized trees will be cut in the next cutting cycle.

The Morisita's index of dispersion (Morisita, 1959) for $S$. curtisii from demographic plot 2 before logging was greater than one $\left(I_{\mathrm{d}}=1.63, P<0.05\right)$ indicating that the distribution pattern of this species is clumped or gregarious in the ridge crests of hill dipterocarp forests (Fig. 2a). Smith and Smith (2001) reported that clumped or gregarious distributions among plants are often influenced by the nature of propagation and specific environmental requirements as well as seed germination and survival of seedlings. The clumped occurrences of $S$. curtisii are correlated with the special features of the habitat (Whitmore, 1984). Burgess (1969) in his autecological study of S. curtisii in Peninsular Malaysia found considerable evidence that $S$. curtisii is restricted to dry sites. Unfortunately, the distribution pattern of $S$. curtisii in plot 2 after logging could not be determined due to limited sample size (Fig. 2b). It will be interesting to examine the long-term effects of logging on the spatial dispersion pattern of S. curtisii.

\section{Discussion}

The mean basal area and tree density in Compartments 40 and 48, Serting Tambahan F.R. and Compartment 118, Ulu Sedili F.R. are fairly uniform among compartments (Table 2). Dawkins (1958) suggested that the basal area of tropical rain forests throughout the world probably ranged between 18 and $50 \mathrm{~m}^{2} \mathrm{ha}^{-1}$ (for trees $\geq 10 \mathrm{~cm} \mathrm{dbh}$ ). This agrees with estimates of basal area in the present study. The changes in primary forest generally are light compared to changes in forest undergoing succession. For instance, Lang and Knight (1983) found that over 10 years, there was a considerable increase in basal area (from 25.7 to $31.4 \mathrm{~m}^{2} \mathrm{ha}^{-1}$ ) and a shift in the number of individuals to larger size classes in a 60year-old forest on Barro Colorado Island, Panama. The RS-C69 can be considered as mature forest as other primary forests in this study, in terms of basal area and tree density recorded (Table 2). For trees $>45 \mathrm{~cm}$ dbh or categorized as large trees in RS-C69 was $53.2 \%$ and $30.3 \%$ more, respectively, in basal area and tree density compared to BF-C118. This means that the abundance of young regenerants are considered before logging operation is commenced in this compartment, as prescribed under MUS. Based on the linear regression analysis, the size class distribution patterns of all trees in the RS-C69 was not significantly different or showed different distribution patterns from that in the BF-C48, in terms of basal area (Fig. 3). Meanwhile other compartments showed significant differences $(P<0.05)$ or similar distribution patterns. For tree density, all compartments showed significant differences $(P<0.05)$ or similar patterns of diameter class distribution (Fig. 4). The frequency distribution in different size classes for tree density showed the strong reverse-J distribution of the type III survivorship curve (Krebs, 1994), suggesting a negative exponential relation in population size between the size classes.

The total reduction in mean basal area for all trees $\geq 1 \mathrm{~cm}$ dbh for both logged compartments was significantly different $(P<0.05)$, i.e. $50.9 \%$ in Compartment 118 and $51.8 \%$ in Compartment 48 


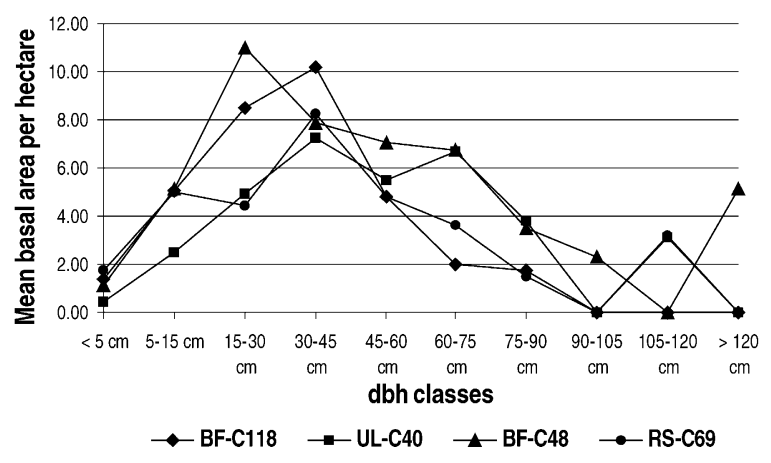

Fig. 3. Diameter class distribution for trees $\geq 1 \mathrm{~cm}$ dbh for basal area $\left(\mathrm{m}^{2} \mathrm{ha}^{-1}\right)$ in four compartments from three forest reserves in Peninsular Malaysia.

under SMS in Peninsular Malaysia. It seems that logging damage to the residual stands was not affected by the cutting limits for the selected species as practised under SMS for both compartments. The extent of damaged is strongly influenced by the nature of the logging practices (Webb, 1997). Thus, harvesting techniques often need to be controlled to decrease the residual damage to acceptable levels. However, the losses recorded here are those immediately after logging and 2.5 years after logging, and there may be further mortality as other damaged trees die. Marn and Jonkers (1982) recorded 35\% mortality of trees suffering minor damage after logging in Malaysia. According to Borhan et al. (1987), under SMS, logging damage to the residuals was estimated at

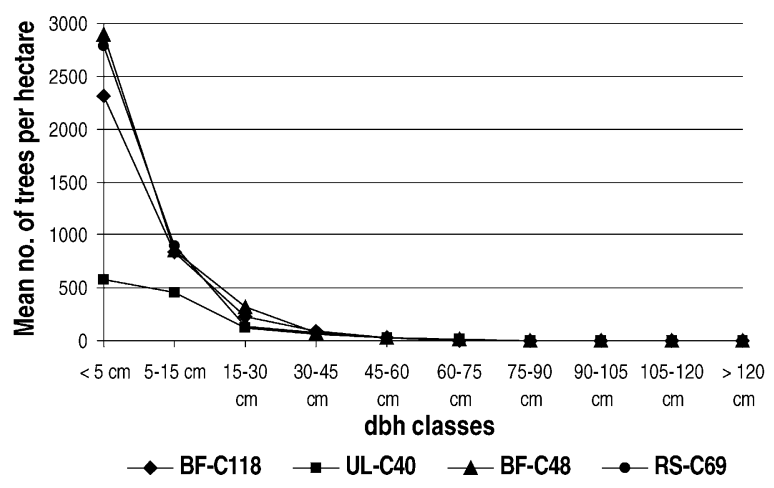

Fig. 4. Diameter class distribution for trees $\geq 1 \mathrm{~cm}$ dbh for tree density (number of trees per hectare) in four compartments from three forest reserves in Peninsular Malaysia. about $8-38 \%$ but Burgess (1971) estimated that the basal area destroyed amounts to $55 \%$ for the extraction of only $10 \%$ of basal area of timber. Therefore, the results obtained in the present study were lower than that reported by Burgess (1971). Canonizado (1978) estimated that logging damage was about $64-69 \%$ in Malaysia.

A successful polycyclic felling programme (e.g. SMS) depends on ensuring that no more than $30 \%$ of intermediate-sized residual trees (of $30 \mathrm{~cm} \mathrm{dbh}$ and above) are damaged (Griffin and Caprata, 1977) and that seedlings and saplings are not destroyed (Aiken and Leigh, 1992). In this study, felling damages to intermediate-sized residual trees were higher than the tolerance level of $30 \%$ estimate, i.e. $49.2 \%$ immediately after logging in Compartment 118 and 39.9\% 2.5 years after logging in Compartment 48. Wyatt-Smith (1954) observed many trees that are only partially affected during logging may appear well initially, but could die several years later. Appanah and Weinland (1990) found that heavy damage from windthrow on a seraya-ridge top several years after logging. Therefore, this will raise logging damage beyond the tolerance level of $30 \%$ as estimated by Griffin and Caprata (1977). The extent of logging roads, skid trials and log-landing sites were slightly higher in Compartment 118 than in Compartment 48, i.e. 2.8\% and 2.4\%, respectively. However, these figures are amongst the lowest recorded; in other studies damage levels of 4.0$26.0 \%$ have been reported (Nicholson, 1958a; WyattSmith and Foenander, 1962; Uhl and Vieira, 1989; Crome et al., 1992). The high proportion of these areas may be related to poor logging control or logging techniques. Log-landing soils were significantly more compacted than the logging roads and skid trials. These areas show very poor recovery of soil properties and vegetation (Malmer and Grip, 1990). In a logged dipterocarp forest in Sabah, 27\% of the area was covered by tractor tracks and $42 \%$ of the seedlings were destroyed (Fox, 1968). Therefore, artificial regeneration via enrichment planting of selected species could be carried out for those areas.

As may be expected, the largest size classes are damaged completely during logging operations, as these are the stems (e.g. the dipterocarp tree species) that are chosen for felling. Chapman and Chapman (1997) reported that highest levels of damage in the largest and also smaller diameter size classes. In 
Compartments 118 and 48 after logging, all trees more than 60 and $75 \mathrm{~cm} \mathrm{dbh}$, respectively, were felled in a single selective cutting under SMS. The removal of these genetically superior adult trees adversely affects the genetic quality of the remaining and subsequent regenerating gene pools. For instance, the reduction in population density of $S$. curtisii adult trees $(\geq 30 \mathrm{~cm}$ $\mathrm{dbh}$ ) after logging (from 15 to 5 trees per hectare) may expose to inbreeding depression and loss of viability. Obayashi et al. (2002) found that the outcrossing rate of $S$. curtisii in the selectively logged plot (52.2\%) was significantly lower than that in the undisturbed plot (96.3\%). This decline of outcrossing rate in the selectively logged plot may result from the low density of conspecific flowering trees and the high rate of selfing. Similar results were also reported by Murawski et al. (1994) for reduction in population density of an insect pollinated dipterocarp species Shorea megistophylla following a selective logging event, which decreased the outcrossing rates.

In Compartment 48, an increase in mean basal area of $24.3 \%$ in seedling and sapling class $(<5 \mathrm{~cm} \mathrm{dbh})$ was observed 2.5 years after logging under SMS. This indicates that logging operation favoured the growth of seedlings and saplings. The net loss in trees was offset by incremental growth in surviving trees. However, the mean basal area and tree density for this diameter class ( $<5 \mathrm{~cm} \mathrm{dbh}$ ) were reduced to onehalf of the original stand in Compartment 118 after logging. Generally, increased growth rates are frequently observed in residual trees following selective logging (Jonkers, 1987; Wan Razali, 1989). The residual trees in moderately and lightly logged areas had a slightly faster growth rate than in the unlogged areas, while the most heavily logged areas had the slowest growth rate (Chapman and Chapman, 1997). Many authors have also reported enhanced growth of dipterocarp seedlings in higher light intensities (Sasaki and Mori, 1981; Whitmore, 1984; Ang, 1991; Manokaran and Swaine, 1994) and growth rates in the logged forest have been correlated with crown exposure (Korsgaard, 1992; Van Daalen, 1993). If canopy openings are too large, the high light intensities may promote the rapid growth of lightdemanding vines and pioneer trees (secondary species), which smother dipterocarp seedlings and other vegetation (Priasukmana, 1989; Cannon et al., 1994; Nussbaum et al., 1995).
However, damage occurred in all size classes as falling trees and logging machinery damaged other stems indiscriminately in the present study. Johns (1988) noted that the distribution of trees across diameter classes did not differ significantly before and after logging and concluded that selective logging was not selective. Both logged stands (Compartments 118 and 48) showed low damage in intermediate size classes. Woods (1989) also revealed a similar finding in a forest logged 2 years previously in Sepilok, Sabah. This is because machinery and falling trees are less likely to break intermediate-sized trees than small sized trees, i.e. small trees, poles, saplings and seedlings. Loggers will also try to avoid intermediate-sized trees as they form the next harvest and they are also easily avoided by bulldozers when making skid trails.

Nicholson (1958a) and Wyatt-Smith and Foenander (1962) reported that damage to residuals (small to large classes) in a lowland forest managed under MUS varied from $28 \%$ to $45 \%$. However, they found sufficient undamaged adolescent trees (about 8-39 trees per acre), which could ensure regeneration of the forests. Nicholson (1958a) also stated that in a recently logged forest in North Borneo under MUS, there remained an average of 10,250 commercial seedlings (less than $1.5 \mathrm{~m}$ tall) per acre. In this study, good regeneration was observed in RS-C69 with $28.5 \%$ and $20.5 \%$ more, respectively, in basal area and tree density for seedling and sapling diameter class $(<5 \mathrm{~cm} \mathrm{dbh})$ compared to BF-C118. These results concur with the results reported by Wickneswari et al. (1997) with $18.3-28.7 \%$ increase in tree density in a regenerated mixed dipterocarp lowland forest compared to an unlogged stand in Peninsular Malaysia. Chapman and Chapman (1997) found that the number of seedlings that emerged from the disturbed soil (seedbank and seedrain) and initially seed-free soil (seedrain) was greater in the logged forest than in the unlogged forest. However, sapling density was much lower in the heavily logged areas, suggesting that there is a high level of seedling mortality in logged areas. On the other hand, Wyatt-Smith and Foenander (1962) noted that the highest loss was saplings and this could be due to the saplings being less able to withstand the sudden canopy opening than the larger trees.

In RS-C69, the mean basal area of small trees (15$30 \mathrm{~cm} \mathrm{dbh)} \mathrm{was} \mathrm{significantly} \mathrm{less}(47.5 \%)$ compared 
to BF-C118 and the tree density was $38.7 \%$ less. This suggests that there is a high level of seedling and sapling mortality several years after logging in Compartment 69. Our data showed that S. curtisii seedlings and saplings in RS-C69 exhibited a substantial reduction of outcrossing rate after logging due to the reduction in population density (data not reported here). Furthermore, the irregular seed production from potential mother trees (sometimes at intervals of 2-5 years) in the residual stand most probably still caused a reduction of basal area and tree density in this class about 50 years after logging. As MUS involves extracting all the trees $\geq 45 \mathrm{~cm}$ dbh in a monocyclic system and removal of mature trees in the stand reduced a significant proportion of the potential seed sources for the establishment of new seedlings (Van Gardingen et al., 1998). Plumptre (1995) found that the density of seedlings rises exponentially with an increase in the number of trees over $50 \mathrm{~cm} \mathrm{dbh}$. However, these results were obtained from only 1 year of phenological records and it is possible that for some species it was a poor year for fruit production. Studies on fruiting in beech (Fagus sylvatica) showed that as dbh increased the number of years in which a tree fruited also increased (Kaplunovskii, 1972). In contrast, a study of dipterocarp tree species in Malaysia showed that the smaller dipterocarp residuals $(>25 \mathrm{~cm} \mathrm{dbh})$ fruited in a recently logged forest under SMS (Appanah and Mohd. Rasol, 1990). Hence, it is better to produce too many rather than too few seedlings. However, high seedling densities are also detrimental in some cases because they will attract predators or pathogens and lead to higher mortalities (Janzen, 1970).

The high negative correlation of basal area with relative disturbance index (RDI) showed that the relative disturbance for the different plots in Compartments 118 and 48 based on botanical or native name followed the principle of continuum index (CI) (Curtis and McIntosh, 1951). Hence, basal area may be a better indicator for monitoring the extent of relative disturbance levels in the site (Fig. 1). Based on the present study, the degree of disturbance was affected by the type and magnitude of disturbances in each of the localities in the compartment. For instance, RDI value of 2.53 showed that there was low intensity selective logging, logging road and skid trials in plot 4 after logging (AF-P4) (Table 7). Therefore, in general, logging operation is not a homogeneous activity in the forest.

There were no distinct changes in species composition and the number of dipterocarp species observed before and after logging demographic plots in both Compartments 118 and 48 (Tables 5 and 6). Similar results were also observed in RS-C69. However, there was a variation in species composition observed between plots (at different elevations) within a compartment and between compartments. Lieberman et al. (1985) reported that species composition varies subtly in relation to altitude. Thus, floristic variation discerned between the plots was consistently correlated with environmental factors, amongst which physiography was clearly important (Ashton, 1976; Manokaran and Swaine, 1994). Meijer (1970) found that a complete floristic recovery in a heavily logged dipterocarp forests in Sabah but the structural recovery was incomplete after 40 years of logging and the regrowth forest had only $56 \%$ of the standing timber volume of a nearby unlogged forest. Another similar case was observed in Australia, with full floristic recovery in 25 years after logging but structural recovery being incomplete (King and Chapman, 1983). However, these observations were only based on small demographic plots $(20 \mathrm{~m} \times 50 \mathrm{~m})$ or overall 0.3 ha in each of the compartments in the present study. A realistic assessment of changes in species composition can only be obtained from long-term observations over a large area and including sampling of juvenile populations (Manokaran and Swaine, 1994). The longest record of demographic change available (a 34-year period) for tropical rain forest trees (Manokaran and Kochummen, 1987) is still substantially less than the likely generation time of tropical forest trees. Establishing clear changes in floristic composition in tropical rain forest is difficult because the majority of species in any area are represented by only a few trees. Simply by their scarcity, rare species are more likely to disappear from the plot records, but, equally, may reappear from new immigration or from a 'bank' of seedlings and saplings in the population below enumeration size (Swaine et al., 1987). Rare species may be more prone to local extinction as a result of environmental fluctuation (Lieberman and Lieberman, 1987) due to disturbances. 


\section{Conclusions}

The baseline information obtained in the present study may be useful for improving the current harvesting guidelines (i.e. SMS) implemented in Peninsular Malaysia in order to promote regeneration of desired commercial species and as a consequence, sustainability of the forests. The SMS is based on a generalized cutting limit for all trees, i.e. $\geq 50 \mathrm{~cm}$ dbh for dipterocarp species and $\geq 45 \mathrm{~cm}$ dbh for nondipterocarp species. Besides, the SMS does not consider the species abundance in a particular logging regime and the genetic quality of the residuals left behind in the post-harvest stands. Therefore, the following aspects can be incorporated into the SMS based on the findings in the present study: (1) improve current logging methods; (2) adequacy of seedlings on the forest floor before and after logging; and (3) increase number of reproductive trees over $50 \mathrm{~cm}$ dbh.

The reduced impact logging (RIL) techniques are proposed for consideration to improve the current mechanized logging techniques applied in Compartments 118 and 48, which caused severe damage (up to $50.0 \%$ ) in the residual stands. RIL operations generally include the following fundamental technical elements (ITTO, 1996): pre-harvest inventory and mapping, pre-harvest planning of roads and skid trails, pre-harvest vine cutting, directional felling, low stumps, efficient utilisation of felled trunks, optimum width of roads and skid trials, winching of logs to planned skid trails, minimal ground disturbance and slash management. The application of RIL has been shown to significantly reduce damage to the stand caused by logging when compared with conventional logging techniques (Bertault and Sist, 1997). Forest harvested with RIL appears to regenerate faster and with a higher percentage of commercial species compared to those logged under conventional practices. Besides, avoidance of enrichment planting is likely to be an important economic incentive for concessionaires to apply RIL on a concession scale. Some of the skid trails in the RIL are already covered in vegetation 1 year after logging, while in some cases, bare skid trails can still be found 20 years after conventional logging in the same region (Sist et al., 1998; Pinard, 1995). This suggests that residual stands following RIL will be better able to sustain repetitive felling cycles.
Nicholson (1958b) noted that seedling regeneration of dipterocarps depends on: (1) the presence of seedlings on the forest floor before exploitation, which is essential; (2) the ability of these seedlings to remain alive for a long period enough to bridge the interval between seed years; and (3) the ability of these practically dormant seedlings to respond to any light increases due to opening up of the canopy. Therefore, it is useless to expect rapid regeneration after logging in areas with up to $50.0 \%$ damage in the residual stand and inadequate number of seedlings already on the ground. In the present study, seedling and sapling densities were reduced to one-half of those in the original stand in Compartment 118 immediately after logging (Table 3 ). Hence, before logging, a survey of the seedling population should be incorporated into SMS, as already implemented in MUS. If insufficient seedlings are found then the area should not be logged.

The reduction of genetically superior reproductive trees can adversely affect the genetic quality of the remaining and subsequent regenerating gene pools. If only a few reproductive trees are left behind and these are not evenly distributed, the probability of inbreeding will increase by selfing or mating between relatives. For instance, the significant reduction in mean basal area and tree density of small trees (15$30 \mathrm{~cm} \mathrm{dbh}$ ) in regenerated stand of Compartment 69 (about 50 years after logging) was most probably due to irregular seed production from potential mother trees and lack of reproductive trees after logging. Plumptre (1995) found that the density of seedlings rises exponentially with an increase in the number of trees over $50 \mathrm{~cm}$ dbh but some species of large old trees $(>70 \mathrm{~cm} \mathrm{dbh})$ showed a decline in fruit production. According to Appanah (2000), the bigger trees within the species usually produce more seedlings than the smaller individuals. Thus, it is crucial to leaving behind sufficient undamaged good quality reproductive trees to ensure good regeneration in the residual stands.

In the Malaysian context, guidelines and operational manuals for harvesting and logging road construction have been formulated by Forestry Department, Peninsular Malaysia (Benneckendorf, 1994; Anonymous, 1997, 1999; Lohuji and Taumas, 1998). Recently, several derived practices have been formulated as a general guide to redesign and retool field operations with the aim of reducing impact of 
logging on stand production and sustainability (Chin et al., 1996; Weinland et al., 2000). Therefore, if these practices are properly enforced and applied there should be no major problems in reconciling environmental requirements and forest structure integrity with timber management requirements.

\section{Acknowledgements}

We gratefully acknowledge the Forestry Department of Peninsular Malaysia, Forestry Department of Negeri Sembilan and Forestry Department of Johor for granting permission to access the forest reserves. We also thank all the foresters involved in this study for their excellent field assistance in establishing the demographic plots in Compartment 118, Ulu Sedili F.R., Compartment 69, Panti F.R., and Compartments 48 and 40, Serting Tambahan F.R., and species identification. Appreciation is also due to Mr. Quah Eng Seng and Ms. Dasima Ramudin from Forest Research Institute of Malaysia (FRIM) for providing the demographic data of Compartment 48, Serting Tambahan F.R. The funding for this study was provided by Center for International Forestry Research (CIFOR), Ministry of Science, Technology and Environment (MOSTE) through IRPA 01-02-020022 and Malaysia Toray Science Foundation (MTSF) grants. Constructive comments by two anonymous reviewers are acknowledged.

\section{References}

Aiken, S.R., Leigh, C.H., 1992. Vanishing Rain Forest: The Ecological Transition in Malaysia. Oxford Biogeography Series No. 5. Clarendon Press, Oxford.

Ang, L.H., 1991. Effects of open and under planting on early survival and growth of Endospermum malaccense (sesendol), Alstonia angustiloba (pulai) and Shorea parvifolia (meranti sarang punai). J. Trop. For. Sci. 3, 380-384.

Anonymous, 1997. Kod Amalan Pengusahahasilan Hutan Darat Asli Semenanjung Malaysia. Jabatan Perhutanan Semenanjung Malaysia.

Anonymous, 1999. Spesifikasi Jalan Hutan (Jalan tuju dan lorong penarik) untuk Semenanjung Malaysia. Jabatan Perhutanan Semenanjung Malaysia.

Appanah, S., Mohd. Rasol, A.M., 1990. Smaller trees can fruit in logged dipterocarp forests. J. Trop. For. Sci. 3 (1), 80-87.
Appanah, S., Weinland, G., 1990. Will the management systems for hill dipterocarp forests stand up? J. Trop. For. Sci. 3 (2), 140158.

Appanah, S., 2000. Trends and issues in tropical forest management: setting the agenda for Malaysia. In: Proceedings of the Tropical Forest Harvesting: New Technologies Examined. pp. 1-21.

Ashton, P.S., 1976. Mixed dipterocarp forest and its variation with habitat in the Malayan lowlands: a re-evaluation at Pasoh. Malaysian Forester 39, 56-72.

Benneckendorf, W., 1994. Operator's Manual for Forest Road Construction. Malaysian-German Sustainable Forest Management Project Sabah. Report No. 194.

Bertault, J.D., Sist, P., 1997. An experimental comparison of different harvesting intensities with reduced impact and conventional logging in East Kalimantan, Indonesia. For. Ecol. Manage. 94, 209-218.

Borhan, M., Baharudin, J., Quah, E.S., 1987. Studies on logging damage due to different methods and intensities of harvesting in a hill dipterocarp forest of Peninsular Malaysia. Malaysian Forester 50, 135-147.

Brown, J.H., Curtis, J.T., 1952. The upland conifer-hardwood forests of northern Wisconsin. Ecol. Monogr. 22, 217-234.

Burgess, P.F., 1969. Preliminary observations on the autecology of Shorea curtisii Dyer ex King in the Malay Peninsula. Malaysian Forester 32, 438.

Burgess, P.F., 1971. The effect of logging in hill dipterocarp forest. Malayan Nat. J. 24, 231-237.

Cannon, C., Peart, D.R., Leighton, M., Kartawinata, K., 1994. The structure of lowland rainforest after selective logging in West Kalimantan, Indonesia. For. Ecol. Manage. 67, 49-68.

Canonizado, J.A., 1978. Simulation of selective forest management regimes. Malaysian Forester 41, 128-142.

Chapman, C.A., Chapman, L.J., 1997. Forest regeneration in logged and unlogged forests of Kibale National Park, Uganda. Biotropica 29 (4), 396-412.

Chin, T.Y., Gan, B.K., Weinland, G., 1996. The silviculture of logged-over forests in Peninsular Malaysia: current practice and future challenges. The Malaysian Forester 59 (1), 1-18.

Crome, F.H.J., Moore, L.A., Richards, G.C., 1992. A study of logging damage in upland rainforest in north Queensland. For. Ecol. Manage. 49, 1-29.

Curtis, J.T., McIntosh, R., 1951. Upland forest communities in the prairie forest border region of Wisconsin. Ecology 32, 476-496.

Dawkins, H.C., 1958. The management of natural of natural tropical high forest with special reference to Uganda. Commonwealth Forestry Institute Paper No. 34.

Fox, J.E.D., 1967. An enumeration of lowland dipterocarp forest in Sabah. Malaysian Forester 31, 89-100.

Fox, J.E.D., 1968. Application of ecological research on silviculture in the lowland dipterocarp forest of Sabah. In: Proceedings of the Symposium on Recent Advances in Tropical Ecology. pp. 710-720.

Griffin, M., Caprata, M., 1977. Determination of cutting regimes under selective management system. In: Proceedings of the ASEAN Seminar on Tropical Rainforest Management, Forestry Department Peninsular Malaysia, Kuantan, Malaysia, 1-10 November. 
Hartshorn, G.S., 1989. Sustained yield management of natural forests: the Palcazu production forest. In: Browder, J.O. (Ed.), Fragile Lands of Latin America: Strategies for Sustainable Development. Westview Press, Boulder, pp. 130138.

Hendrison, J., 1990. Damage-controlled Logging in Managed Rain Forest in Suriname. Agricultural University, Wayeningen, The Netherlands.

ITTO, 1996. Reduced impact, increased costs?—do reduced impact logging regimes also reduce profits for forest operators? Trop. For. Update 6 (3).

Janzen, D.H., 1970. Herbivores and the number of tree species in tropical forests. Am. Nat. 104, 501-528.

Johns, A., 1988. Effects of selective timber extraction on rain forest structure and composition and some consequences to frugivores and foliovores. Biotropica 20, 31-37.

Johnson, N., Cabarle, B., 1993. Surviving the Cut: Natural Forest Management in the Humid Tropics. World Resources Institute.

Johns, J.S., Barreto, P., Uhl, C., 1996. Logging damage during planned and unplanned logging operations in the eastern Amazon. For. Ecol. Manage. 89, 59-77.

Jonkers, W.B.J., 1987. Vegetation Structure, Logging Damage and Silviculture in a Tropical Rain Forest in Suriname. Agricultural University, Wageningen, The Netherlands.

Kaplunovskii, P.S., 1972. Fruiting behaviour in beech stands. Lesoved 1, 51-61.

King, G., Chapman, W., 1983. Floristic composition and structure of a rain forest area 25 years after logging. Aust. J. Ecol. 8, 415423.

Korsgaard, S., 1992. An analysis of growth parameters and timber yield predication. The Council for Development Research, Copenhagen, Denmark.

Krebs, C.J., 1994. Ecology: The Experimental Analysis of Distribution and Abundance, 4th ed. Addison-Wesley/Longman, USA.

Lang, G.E., Knight, D.H., 1983. Tree growth, mortality, recruitment and canopy gap formation during a 10 -year period in a tropical moist forest. Ecology 64, 1075-1080.

Lee, C.T., 1999. Effects of logging on the genetic diversity of Scaphium macropodum and Parkia speciosa. M.Sc. Thesis. Universiti Kebangsaan Malaysia.

Lieberman, D., Lieberman, M., 1987. Forest tree growth and dynamics at La Sleva, Costa Rica (1969-1982). J. Trop. Ecol. 3, 347-358.

Lieberman, M., Lieberman, D., Hartshorn, G., Peralta, R., 1985. Small-scale altitudinal variation in lowland wet tropical forest vegetation. J. Ecol. 73, 505-516.

Lim, M.S., Chin, C.T., 1995. A practical approach to conservation of genetic diversity in Malaysia: genetic resource areas. In: Proceedings of an IUFRO Symposium on Measuring and Monitoring Biodiversity in Tropical and Temperate Forests. pp. 207218.

Lohuji, P.L., Taumas, R., 1998. RIL. Operation Guide Book Specifically for Tracked Skidder Use, Sabah Forestry Department.

Malmer, A., Grip, H., 1990. Soil disturbance and loss of infiltrability caused by mechanised and manual extractions of tropical rainforest in Sabah, Malaysia. For. Ecol. Manage. 38, 1-12.
Manokaran, N., 1996. Effect, 34 years later of selective logging in the lowland dipterocarp forest at Pasoh, Peninsular Malaya and implications on present-day logging in the hill forests. In: Proceedings of the Malaysia-United Kingdom Programme Workshop on Conservation, Management and Development of Forest Resources, pp. 41-60.

Manokaran, N., Kochummen, K.M., 1987. Recruitment, growth and mortality of tree species in a lowland dipterocarp forest in Peninsular Malaysia. J. Trop. Ecol. 3, 315-330.

Manokaran, N., Swaine, M.D., 1994. Population dynamics of trees in dipterocarp forests of Peninsular Malaysia. Malayan For. Rec. 40.

Marn, H.M., Jonkers, W., 1982. Logging damage in tropical high forest. In: Srivastava, P.B.L. (Ed.), Tropical Forests, Source of Energy through Optimisation and Diversification. Penerbit Universiti Pertanian Malaysia, Serdang, pp. 2738.

Mason, D., 1996. Responses of Venezuelan understory birds to selective logging, enrichment strips and vine cutting. Biotropica 28 (3), 296-309.

Matthews, J.D., 1989. Silvicultural Systems. Oxford University Press, Oxford.

Meijer, W., 1970. Regeneration of tropical lowland forest at Sabah, Malaysia forty years after logging. Malayan Forester 33, 204 229.

Morisita, M., 1959. Measuring the dispersion of individuals and analysis of the distributional patterns.. Mem, Fac. Sci. Kyushu Univ. Ser. E (Biol.) 2, 215-235.

Murawski, D.A., Gunatileke, I.A.U.N., Bawa, K.S., 1994. The effects of selective logging on inbreeding in Shorea megistophylla (Dipterocarpaceae) from Sri Lanka. Conserv. Biol. 8, 997-1002.

Narayanan, I.V., Swarupanandan, K., 1996. Regeneration dynamics and sylvigenesis in the moist deciduous forests of southwest India. New For. 11, 185-205.

Nicholson, D.I., 1958a. An analysis of logging in tropical rain forest, North Borneo. Malayan Forester 21 (4), 235245.

Nicholson, D.I., 1958b. Natural regeneration of logged tropical rain forest, North Borneo. Malayan Forester 21, 65-71.

Norusis, M.J., 1993. SPSS/PC+ Statistics 6.0 for Window. SPSS Inc., Chicago.

Nussbaum, R., Anderson, J., Spencer, T., 1995. Effects of selective logging on soil characteristics and growth of planted dipterocarp seedlings in Sabah. In: Primack, R.B., Lovejoy, T. (Eds.), Ecology, Conservation and Management of Southeast Asian Rainforest. Book Crafters Inc., Yale University.

Obayashi, K., Tsumura, Y., Ihara-Ujino, T., Niiyama, K., Tanouchi, H., Suyama, Y., Washitani, I., Lee, C.T., Lee, S.L., Norwati, M., 2002. Genetic diversity and outcrossing rate between undisturbed and selectively logged forests of Shorea curtisii (Dipterocarpaceae) using microsatellite DNA analysis. Int. J. Plant Sci. 163 (1), 151-158.

Pinard, M.A., Putz, F.E., 1996. Retaining forest biomass by reducing logging damage. Biotropica 28, 278-295.

Pinard, M.A., 1995. Carbon retention by reduced impact logging. Ph.D. Thesis. University of Florida, USA. 
Pinard, M.A., Putz, F.E., Tay, J., Sullivan, T.E., 1995. Creating timber harvest guidelines for a reduced-impact logging project in Malaysia. J. For. 10, 41-45.

Plumptre, A.J., 1995. The importance of "seed trees" for the natural regeneration of selectively logged tropical forest. Commonwealth For. Rev. 74 (3), 253-258.

Priasukmana, S., 1989. Planting experiments of dipterocarps in East Kalimantan. In: Soerianegara, I., Tjitrosomo, S.S., Umaly, R.C., Umboh, I. (Eds.), Proceedings of the Fourth Round-table Conference on Dipterocarps. Biotropical Special Publication 41, Bogor.

Sasaki, S., Mori, T., 1981. Growth responses of dipterocarp seedlings to light. Malaysian Forester 44, 319-345.

Sist, P., Nolan, T., Bertault, J.G., Dykstra, D., 1998. Harvesting intensity versus sustainability in Indonesia. For. Ecol. Manage. 108, 251-260.

Smith, R.L., Smith, T.M., 2001. Ecology and Field Biology, 6th ed. Addison-Wesley/Longman, USA.

Swaine, M.D., Lieberman, D., Putz, F.E., 1987. The dynamics of tree populations in tropical forest: a review. J. Trop. Ecol. 3, 359-366.

Thang, H.C., 1987. Forest management systems of tropical high forest, with special reference to Peninsular Malaysia. For. Ecol. Manage. 21, 3-20.

Uhl, C., Vieira, I.C.G., 1989. Ecological impacts of selective logging in the Brazilian Amazon: a case study from the Paragominas region of the state of Para. Biotropica 21, 98106.

Van Daalen, J.C., 1993. The value of crown position and form as growth indicators in mixed evergreen forest. S. Afr. For. J. 165, 29-35.

Van Gardingen, P.R., Clearwater, M.J., Nifinluri, T., Effendi, R., Rusmantoro, W., Noor, M., Mason, A., Ingleby, K., Munro, R.C., 1998. Impacts of logging on the regeneration of lowland dipterocarp forest in Indonesia. Commonwealth For. Rev. 77 (2), $71-82$.
Walton, A.B., 1954. The regeneration of dipterocarp forests after high lead logging. Empire For. Rev. 33, 338-344.

Wan Razali, W., 1989. Summary of growth and yield studies in tropical mixed forests. Project Paper UNDP/RAS/86/049. UNDP. FRIM Reports No. 49. Forest Research Institute Malaysia, Kepong.

Webb, E.L., 1997. Canopy removal and residual stand damage during controlled selective logging in lowland swamp forest of northeast Costa Rica. For. Ecol. Manage. 95, 117-129.

Weinland, G., Bauernfried, P., Gan, B.K., 2000. Immediate solution to an old problem: re-designing and re-tooling of the traditional ground skidding logging system. In: Proceedings of the Tropical Forest Harvesting: New Technologies Examined. pp. 60-75.

White, L.J.T., 1994. The effects of commercial mechanised selective logging on a transect in lowland rainforest in the Lope Reserve, Gabon. J. Trop. Ecol. 10, 313-322.

Whitmore, T.C., 1984. Tropical Rain Forests of the Far East, 2nd ed. Oxford University Press, Oxford.

Wickneswari, R., Lee, C.T., Norwati, M., Boyle, T.J.B., 1997. Effects of logging on the genetic diversity of six tropical rainforest species in a regenerated mixed dipterocarp lowland forest in Peninsular Malaysia. Wrap-up Workshop of the CIFORIPGRI on Impact of Disturbance Project, Bangalore, India, 18-22 August.

Woods, P., 1989. Effects of logging, drought and fire on structure and composition of tropical forests in Sabah, Malaysia. Biotropica 21, 290-298.

Wyatt-Smith, J., Foenander, E.C., 1962. Damage to regeneration as a result of logging. Malayan Forester 25, 40-44.

Wyatt-Smith, J., 1954. Survival of isolated seedbearers. Malayan Forester 17, 30-32.

Wyatt-Smith, J., 1963. Manual of Malayan Silviculture for Inland Forests, vol. I. Malayan Forest Records No. 23. FRIM, Kepong, Kuala Lumpur.

Wyatt-Smith, J., 1988. Letter to the Editor. For. Ecol. Manage. 24, 219-223. 